\title{
Further Considerations on the Politics of Religious Discourse: Naim Frashëri and his Pantheism in the Course of Nineteenth-Century Albanian Nationalism
}

\author{
ENIKA ABAZI* AND ALBERT DOJA**
}

In the standard tradition of both Albanian studies and Western scholarship, including either any interested religious and political activism or less 'interested' lay people, endeavors of historical and textual fact-finding have been relevant only to reconfirm and indeed perpetuate the very meaning of a myth, according to which the thinking of Naim Frashëri was formed and dominated by Bektashism and that his 'Albanianism' had a Bektashi foundation. In an earlier paper this myth is shown to be unreliable by arguing that Frashëri's religious thinking was shaped by religious dualism. ${ }^{1}$ In this article we intend to argue further that Naim Frashëri went far beyond Bektashism in his heterodoxy, not only in a kind of liberation theology, but also by embracing a comprehensive pantheism which generated an active and allinclusive attitude to Albanian identity, not necessarily limited in any special way to Bektashism. Methodologically, such a new picture must arise if the analysis of the historical and literary contextualization of Frashëri's major works is submitted to the perspective of social theoretical approaches to religion developed in sociology and anthropology.

The way Albanian national 'renaissance' (Rilindja) developed after the predictable fall of the Ottoman Empire, in a period from the mid-nineteenth century to the Declaration of Independence in 1912, showed that language and history were treated as the most important 'cultural stuff' ${ }^{2}$ to argue for common 'essential' and 'authentic' Albanian values and demarcate national boundaries. By contrast, the force of religion in providing a universal and transcendent foundation for collective association had to be considered by the Albanian activists of the time as counterproductive in shaping a national identity myth. ${ }^{3}$ Even though religious shifting must have been instrumental in

\footnotetext{
*Doctoral College, PRES University of Lille Nord de France. Email: Enika_Abazi@yahoo. com.

**Institute of Sociology \& Anthropology, University of Sciences \& Technologies of Lille 1, Cité Scientifique SH2-215, 59655 Villeneuve d'Ascq, France. Email: albert.doja@univ-lille1.fr
} 
the reconstruction of identities in multi-religious Albania, ${ }^{4}$ claims to show the exclusive 'birth of a nation of Muslim majority in Europe', 5 which are based on a deliberate use of selective data and an exaggerated point of their own, not only essentialize and reify a given nation, but ultimately work for the ideological purpose of civilizational drift within Europe itself. In fact, more than anything else religious division was a threat to Albanian unity, and considering the difficult history of the assertion of the Albanian national identity, a great number of Albanian Muslims, despite their 'divided loyalty', ${ }^{6}$ may have expressed the desire to sever links with the Ottoman Empire. ${ }^{7}$ Among others, the political position of the Bektashis is particularly revealing.

While it is claimed, not only by Bektashi leaders, ${ }^{8}$ but also by modern scholars of Bektashism, ${ }^{9}$ that the Bektashis must have played, comparatively speaking, a remarkable role in shaping Albanian nationalism in the late nineteenth and early twentieth centuries, it is our contention that beyond a traditionally assumed difficult relationship of Bektashism with the religious and political Ottoman authorities, ${ }^{10}$ their choice of an anti-Turk and nationalist stance must have gone along with a reinforcement of the heterodoxy characteristic of their system of beliefs and practices. And it is certainly not surprising that Naim Frashëri (1846-1900) was particularly instrumental in that direction. He is better known as one of the greatest Albanian poets and activists of the Albanian national movement in the nineteenth century, striving to establish a unified written Albanian language and to glorify the Albanian past in a literature of his own, ${ }^{11}$ which must have inspired Albanian national union and helped the affirmation of Albanian-speaking people as a modern nation. At the same time, not only did he contribute to Bektashi literature but arguably he explained and to some extent founded, or at least promoted, in his Bektashi Notebook, ${ }^{12}$ the novel theological and practical principles of Bektashism and the organizational rules governing its functioning.

In addition, while in local scholarship of either a religious or nationalist cast there is little room for the notion of multiple and overlapping identities, ${ }^{13}$ we must recognize Frashëri's long and distinguished career in the service of the Ottoman state, ${ }^{14}$ as well as his own and his younger brother's monumental contributions to Turkish language and culture. ${ }^{15}$ This is especially intriguing if we recall that Naim Frashëri was at first not linked to any national identity politics, even at the time of the League of Prizren (1878-81), ${ }^{16}$ which is considered to be the founding event of Albanian nationalism and of which his elder brother was one of the most prominent leaders. ${ }^{17}$ From a dreamy individual, lost in the gloomy lyrics of his 'Reveries' in Persian, ${ }^{18}$ and a committed official of the state administration with many links of loyalty to Ottoman power, he suddenly turned into the most brilliant promoter of the Albanian language and the most influential activist of the Albanian national movement, in flagrant opposition to the Ottoman regime.

This does not rule out exclusionary dichotomy in the thinking of Frashëri with regard to the Ottomans and Albanianism, but we need subtler and historically more sensible terms to accurately reflect people like him. Whatever term we think of, any qualification of his position must necessarily fit with an emphasis on the universalistic dimensions of his intellectual orientation, just as was the case with his younger brother, whose works generally consisted of a combination of Oriental and western writing styles. ${ }^{19}$ As shown in more detail elsewhere, ${ }^{20}$ as an author and thinker who was consciously open-minded to all cultures and civilizations, and freed from any 
Eurocentric or Asia-centric complex, Naim Frashëri must have subsumed and reconciled in his work different philosophical currents of thought and poetic experiences, from both eastern and western traditions.

In connection with this argument, some qualification of the supposed Bektashi background and inspiration of his work and activism does not necessarily diminish his commitment to both Bektashism and Albanianism. On the contrary, our analysis aims to introduce an innovative way of looking at the relationship of religious identity to political mobilization, with a potential to bring forth insights into the situations in which group identities are being negotiated and redefined.

In fact, the analysis of transformations in doctrinal-ideological and structuralorganizational patterns that are clearly evidenced by the development of Bektashism throughout its history, depending on different political contexts and the course of events, as much in the classical Ottoman period and in the reformed Ottoman system or in modern Turkey ${ }^{21}$ as in independent Albania or in the Albanian post-communist period, ${ }^{22}$ suggests that it is precisely on structural and ideological grounds that the dialectical correlation between religious innovation and political projects may be addressed. ${ }^{23}$ Along these lines, Frashëri's intellectual speculations in the context of the Albanian national movement can be shown to be situated in the stage of development of religious ideas that must have corresponded to the promotion of the historical heterodox traits of Bektashism as a liberation theology.

While the liberation theology background worked out from Bektashism, and which must have provided some inspiration to Frashëri's work and activism, is examined elsewhere in more detail and in its own right, ${ }^{24}$ it is our intention to argue here that the best way for Frashëri to overcome Manichaean dualism and build his nationalist ethics was to take on board another heterodox trait from Bektashism, namely pantheism, which for both orthodox Islam and Christianity is traditionally considered a heretical belief. It is therefore important to examine here in more detail through a careful contextual analysis how Bektashi pantheism is not only fully acknowledged but even furthered in Frashëri's national ethics. Following a long tradition of a universalist streak within Sufism as we know it from Hodgson's discussion of later Sufism in the Muslim East, ${ }^{25}$ the argument is not necessarily that it is the nationalist conceptualization that influenced Frashëri's conception of heterodoxy and pantheism, but rather that the way which he perceived humankind as the most perfect expression of God gave way to the idea that Albanians as a collective were part of this expression, and therefore deserved to have their collective rights in the same way as other peoples.

The analysis of the historical and literary contextualization of Frashëri's discourse closely related to Bektashi symbolism of pantheism is expected to clarify some peculiarities of the Albanian context, namely the separation of religious from ethnic elements as a distinctive feature of the Albanian nationalist movement, and to illustrate the inadequacy of religious paradigms in conceiving Frashëri's nationalist project. Understanding how these ideological elements are emphasized in Frashëri's works should lead, against Bektashi claims supported by current scholarship quoted above, ${ }^{26}$ to an understanding of the way in which Bektashi symbolism is aimed to be de-confessionalized in conformity with an Albanian nationalism that transcended confessional allegiances. Ultimately, just as Frashëri's Bektashi themes and texts are better understood as instrumental to the politics of Albanian nationalism rather than as reflecting the tenets of Bektashism, we argue that the Bektashi political claims of 
an active role in the Albanian nationalist movement must be demystified, for we can rather consider the active role of nationalism in the rise of Bektashism in Albania.

Amongst the Bektashis in Albania, some relevant features of the Bektashi vision related to the belief in Divinity in all forms of life and in nature were a consequence of their acceptance of the monism of Hurufi theosophy and especially Ibn-Arabi's pantheistic belief in the Unity of Existence (wahdat-al-wujud). Also, the Bektashi affirmation of Ali's divine status recalls that such adoration was to be found amongst the most extremist sects of Islam. Elsewhere, in the Islamic world, the response by mainstream Muslims is mixed, ranging from downright condemnation of Ibn-Arabi's pantheistic principles to a frank condemnation of the Hurufi aberrations of 'popular' Sufism which is openly accused of pantheism. ${ }^{27}$ Such excesses of both 'popular' and 'higher' Sufism's pantheistic flights are viewed as a perversion of the true message of Islam.

Hurufism was throughout its history, at all times and in all places, including its followers in the Balkans, a popular and radically heterodox movement. In some Muslim quarters, the Hurufi founder is deemed to be the arch-heretic of all time and in all Islam, including many dervish sects of extremist Shiite inclinations. ${ }^{28} \mathrm{He}$ is accused of being an advocate of heterodox beliefs which sowed seeds of corruption of faith and apostasy wherever the allegedly insidious and semi-magical Hurufi doctrines spread. Again, Hurufism was born out of suffering, and out of a long memory of suffering, especially the suffering of the martyrs of Karbala. Martyrdom will be repeated, endlessly, although primarily it was centred in the Hurufi founder's own martyrdom in the first quarter of the fourteenth century and in the horrific martyrdom of his best known disciple. It is the latter's example as a martyr and a poetic expression of Hurufism that captured the imagination of Bektashism, ${ }^{29}$ which was to become the semi-official Sufi depository of Hurufi classics.

Indeed, the Hurufis were to be found amongst the Bektashis, especially in the Balkans, in Albania and in Kosovo. Yet many of them eschewed the reference to Hurufism, even though their view of God and the universe had much in common with Hurufi thought. In any case Hurufism had a marked influence upon the popular Sufi poets of the Balkans, especially in Albania. Actually, the essential message of Monism and the advocation of metempsychosis, derived from Hurufi poetic elaborations as well as directly from Ibn-Arabi's thought, according to Norris, were brought home by the fervent nationalist aims of the greatest among these poets, Naim Frashëri, who was perhaps the most typical of such poets in southeast Europe. $^{30}$

In his creative writings, Frashëri deliberately emphasized his pantheistic philosophy, the doctrine that God is the ultimate reality of which the material universe and human beings are only manifestations, which best indicates the nature of his Bektashi mysticism and the strong influence of Hurufi classics. Instead of the axiomatic theology of 'no other gods but God' aimed at the control of the mystic ways of traditional orthodox Sufism, ${ }^{31}$ Frashëri emphasized the pantheistic inspiration of 'everything is God' and made a similar point found in either Ismaili or Hurufi literature where Man's nature is the very Book of God and all Nature is the manifestation of Deity, for all is conceptually connected to God, as a reflection of God and reflecting back to God. Throughout Frashëri's writings, God is everywhere, in what is visible and 
invisible to human perception; God is everything; and everything, regardless of the forms it takes, has its source in God, since God is the universe that never dies.

Frashëri's musings on nature, its lawfulness and the place of human destiny in it, are spanned by a pronounced metaphysical pathos, especially in his poems of philosophical thinking, when he strived to know how the being of the world is shaped. ${ }^{32}$ At first sight, these meditations seem to be traversed by the anxiety of human beings going along with the flow of time into the unknown of nothingness, ${ }^{33}$ but above all we have here what in mystical language is known as 'extinction into fusion' (fana). Yet, unlike other Muslim mystics who claim to merge into God (fana-fi-Haqq), the Prophet (fana-fi-Rasul) or one's own Sheikh (fana-fi-Pir), Frashëri claimed to merge into the harmonious unity of the universe.

His first collection of poems in Persian opened with a poem dedicated to the $S k y$, and not with a poem dedicated to God as was the tradition of Persian poets over the centuries. Deviating from such a scheme is not necessarily related to 'his ideological stance against religion', as is very often tendentiously stated by some local scholars, ${ }^{34}$ but to the attraction of the cosmic theme, which remained one of the central motifs of his lyrical musings. ${ }^{35}$ Through the collection's structure he confirmed the leitmotif of his poetry, the cosmic vision of God merged into the universe, into nature and humankind. This vision is not simply philosophical, but also ethical, and is related to Frashëri's humanistic universalism in a kind of utopian ideal of humankind and human harmony, as manifestations of cosmic harmony involving God in every aspect.

In his arguments Frashëri took part in the well-known discussions of Arabian philosophy about the nature of God and its attributes. Certainly, a kind of theism was associated with the beginnings of his creative work, similar to the Koranic representations of Muslim theologians who regarded God as a creative and driving power outside nature and the universe. From a heavenly throne and with a supernatural will, the eternal, almighty and omniscient God directed the flow of the world and human destinies, observing and knowing everything, rewarding the good and punishing the wicked. ${ }^{36}$ But with Frashëri's creative maturity, the concept of God increasingly took the heretical form of pantheism where God is identified with the universe, with everything in nature that can be seen, that can be heard and that can be imagined. This concept permeated almost all of Frashëri's poetic art, even though pantheism is more specific to his meditative and national-historical poetry, as 'are typically some verses of the Spring Flowers collection that show the most comprehensive formulation of the concept of the poet thinking about being and existence of the world'. ${ }^{37}$ In fact, for Frashëri, God is nothing but all nature in its diversity, which is nothing but the infinite area where God appears and reappears. God's power lies nowhere but in its ability to show itself as the universal and eternal essence of the infinite variety of what makes up what is called the universe.

The concept of God, according to Frashëri's Bektashism, is without beginning and without end, for God is all the cosmos, anything that can be. The concept of the beginning does not bother the idea of the infinity of Bektashi God, which is the Goduniverse, since the universe itself is God. However, God that is the universe and the universe that is God, according to Frashëri, is not just a tangible thing but also the very spirit, which is also unlimited and illimitable and which cannot be separated and understood outside the matter. Basically the essence of Frashëri's Bektashi worldview is pantheism, which abolishes the boundary between the living and the 
dead, between inorganic substances and the organic world, between things and beings. This is very special, and this pantheism that precludes absolutely nothing at all is actually the generalizing idea of God as the universe and of the universe as God. The matter-spirit duality makes no other sense than just a conventional meaning of the boundaries of things and beings in the world, as matter is also the spirit and spirit is also the matter.

In this way, God is the immanence of nature, identified with the world, unlimited in space and infinite in time. God is the matter, but also the spirit; the generalization of matter and spirit; a generalization of the world of things and the world of ideas: 'Whatever you see is God of Truth, Whatever you listen is its Voice, God is anything that exists and whatever does not in life ... Whoever speaks and whatever is spoken, Whatever is seen and whatever cannot in life, Who sees and what is seen, There is the God of Truth'. ${ }^{38}$ In many of Frashëri's verses God is not an omnipotent and transcendental being that is above and beyond nature, as usually represented in the world's great religions, but a sublime appearance of the spirit inherent to the matter and the magnificent aspect of the universe. God is something that is not above and beyond the world, but within the world and inherent to it, fully merged and made one with nature and humankind.

The pantheistic understanding of the world, where matter, soul, spirit and life are in everything and are nothing else but the manifestation of God, evokes fervent feelings of a cosmic love, a passion for everything, towards the immeasurable profundities of the spirit and towards the unlimited spaces of the world. At the first glance of some scholar, ${ }^{39}$ this worldview seems to fit only people with an esoteric life, a deprived life, focused towards contemplation of the soul, and denying any intention to go out in the world, any will for social needs and change, any ambition for transformations and cultural or political reforms. Yet, as also shown by many other scholars, ${ }^{40}$ there is obviously a doctrinal position in embracing such a worldview, which first disclosed Frashëri's heterodoxy as opposed to orthodox dogma, but also the search for an ethical and philosophical path leading to the ideas of human moral perfection and harmony, and ultimately, in so far as the moral perfection and harmony of the Albanian people is meant, to the active militant secularist and particularist ideology of Albanian nationalism.

Among the religious and philosophical theories and concepts favoured by Frashëri, pantheism implied a relationship of the unity and identity of the soul to the body or the subject to the object in general, and especially the goal of national identity. The purpose of the elaboration and development of such concepts was definitely Frashëri's need to politically meet and actualize the national requirements and duties of his activism, namely the creation of Albanian national unity and harmony and the idea that through the transformations resulting from self-denial and resistance the freedom and prosperity of the past could be repeated and renewed.

Beyond the limits of the traditional mysticism of Sufi poetry, Frashëri did not mystify God. In a number of verses and educational works, actually surpassing pantheistic conceptions evolved in mainstream Bektashism, he stressed in unusual ways that the sacred book of Bektashis is their faith in the universe: 'Wherever I look in this life, I see you God of Truth! Your book is the Universe; Those who know may read it' ${ }^{41}$ Further, there is especial emphasis in relation to human beings. The true faith is written nowhere, not in any book, but rather in the human heart, since 'the Book is the 
human kind' ${ }^{42}$ 'To come out itself, The great God of Truth! Give life to humankind, As know those who know'. 43

Frashëri's Bektashi Notebook is commonly assumed to be overwhelmingly orthodox Bektashi and indeed entirely Muslim in its message. However, at certain points Hurufi influences are clearly discernible, especially in the section of original poems embodying the pantheistic philosophy of Bektashism and where he openly confessed to his own pantheistic beliefs. He declared that 'for the Bektashi the Universe is God', an affirmation of wahdat-al-wujud, and he added that

in this world Man is the representative of God ... All things are in man, yea, even the God of Truth, since when He wished to manifest Himself; He made man in His image and likeness ... For the Bektashi the book of religion is the universe and above all the humankind, as Ali said, Man is the book that speaks by itself, religion is an added word by those who don't know, religion is in the human heart, not written anywhere on paper. ${ }^{44}$

Not only did Frashëri cast God in things, but seeing the universe as an image of God, he even ventured to enter it. Believing in the strength of the human mind, which is not unrelated to his pantheism, he made a claim that to understand God men should carefully observe the universe. By means of God, Frashëri brought men into nature and called them to study and know it, looking at the universe as an open book, which they must constantly try to read. In this way, they could read the meaning of the world and mentally penetrate into it. The more they study and know the essence of nature, the better they come to know God: 'As an erudite have a look at the high sky! You shall find the throne of magnificent clarity'. ${ }^{45}$

Of course enjoyment of all that is on earth and making the effort to know about them would be a perfectly sensible Bektashi position. However, another overt step where Frashëri moved out from classical vision or narrowed it down, is in his taking God from heaven down to earth, where the divine, included and unified in nature, has no power other than to materialize itself into the infinite variety of things of the world, and hence to become available to be known. Especially the verses in his Heaven and Flying Speech collection clearly show that for Frashëri God was no longer a secret power far away from the human world, but a power that shows itself at any moment, and that human beings can see and know, approach and reach. ${ }^{46}$

The opinion expressed in the verse on 'God' in the Spring Flowers collection, according to which one will achieve knowledge 'Up to the throne of God', even though it might have seemed for some just a rhetorical statement by Frashëri as a thinking poet, ${ }^{47}$ precisely because God is everywhere, in nature and in humankind, everyone could feel God within themselves and, by feeling, could explain it to themselves. It is not surprising, therefore, that knowing the essence of God and the universe is conditioned by human knowledge and wisdom: 'God is there to daylight, The blind cannot see, God is the universe, The wise must recognize'. ${ }^{48}$

The ancient heritage of Islamic esoteric knowledge (al-batin) is forcibly reexpressed in his conviction that one may know the nature of divinity within one's own being, body, and especially beauty of visage. The features of human being are the mirror of divinity: 'When God first sought to show his face, He made mankind 
his dwelling place. One who knows one's inward mind, knows that God is the mankind' ${ }^{49}$ One strives in vain to seek God in heaven or on earth, while God is present within everyone. Only by knowing one's own self deeply can one know the whole God, just as the real believer should know that God is not in the heavens, but inside the human heart: 'I was looking everywhere to find God, the great God of Truth; it was inside me, myself I had it inside..$^{50}$

In Frashëri's poetic and philosophical thought, if pantheism naturally leads to the deification of the universe, since everything takes part in God's existence and is part of God, then pantheism implied the possibility of recognition of God within humankind, which eventually leads to the acceptance of deification and the moral 'sanctification' of men themselves, since God appears in a perfect form within the human soul. This may be old wisdom and standard imagery in Bektashi poetry, but at Frashëri's hand the basis of all existence is as much spiritual as moral progress. In addition, the spiritual and the moral are not separate from the material and the natural, the link between them is intimate and the integrated self, which is submerged into the Cosmic self, has no difficulty in recognizing this.

If the position of Man is above all creatures in Frashëri's philosophy, this is because Man contains the realities of all things. In other words, the forms of all entities exist briefly in the fact of Man. For Frashëri, humankind is the ultimate goal and achievement of the divine scheme, a superior meaningful and purposeful configuration of God, because men are endowed with moral conscience: 'Look carefully at humankind, So you must know God's wisdom ... There is no higher in life, But humankind of Truth', ${ }^{51}$ 'The Heart of human life, is the place of God, is there the God of Truth, the great sea of the universe'. ${ }^{52}$ Humankind is the moral qualification of God, whereas God is the ethical support to men in their daily lives. Through such statements Frashëri sought to act upon positive moral values. For Frashëri, if God is not an absolute but a relative being, God is not strictly separated from communication to humankind but is symbolically and representationally subject to the ethical structure of coexistence and communication with humankind, which thereby receives divine features and quality.

Surely, this superiority is seen everywhere as the mirror of God's names and attributes, sometimes referred to as the 'light of God'. In Frashëri's first collection of poems written in Persian and elsewhere, he certainly described the magnificence of mankind as a microcosm and the world at large as a macrocosm and he relied on Hurufi and Bektashi conceptions that locate the letters of Revelation and the signs of Zodiac in Man. ${ }^{53}$ Yet Frashëri does not simply cast Man as a microcosm reflecting within himself the macrocosm in miniature, but arguably his verse on 'Divinity' can be rather read as representing the ultimate reality of God and all that exists in the Cosmos as a projection of Man: 'You are the whole life, You are the Universe, Selfmade a Man you are, You did take His own face'. ${ }^{54}$

Another important aspect of Frashëri's creative work and activism can be shown to be shaped by theories of metempsychosis and metamorphosis as well as ideas of the transmigration and transubstantiation of the soul of beings and things in nature. Closely related to pantheism, such ideas assume the concept of immortality and the idea of a circular movement of eternal return and renewal as the dominant trend in nature and the human world. Although it might be explained as an influence of neoPlatonist philosophy, the idea of the circular development of nature results from and 
is conditioned by the general worldview and sensitivity that overall affect Frashëri's creative work, in which cosmic poetry occupied an important place. Life and death are processes of eternal return in the cosmos, in a movement of endless transformation of everything from life to death, from matter to spirit, from memory into oblivion, from body into mud and from mud into flower, from past to the future, from winter to spring and vice versa. ${ }^{55}$ This brought Frashëri to the idea of the unity of the world, a continuous outflow and transition to one another, a world or world's 'spirit' the first law of which is the eternal return and continuous renewal of a 'circle of life', which provided him the rationale to work out his transcendental theory and universalist philosophy of the development of the world and humankind: 'We may say this life, Cannot ever remain deserted, The father is buried, But in his own longlived son! The moon is eaten on the waning, But start recovering again; The flowers that in winter die, In spring are they back in life; So said our elders, Circle of life is an eternal return', 56

Because the circular development that qualifies nature and human life is also a social and historical regulation that nourishes hope in human history, the idea of circular development of human life and history must be considered as an expression of Frashëri's nationalist commitment, in so far as he put emphasis on the hope of renewal of freedom and prosperity for the Albanian people. ${ }^{57}$ By extending the idea of circular development in human history, Frashëri argued that even in the lives of his fellow countrymen, freedom, independence and greatness of the past, like that of the time of Skanderbeg, ${ }^{58}$ should be repeated. With this historical case he did not communicate an historical truth, but a moralistic truth. Through the moral potential of the heroic past he wanted to confront the morally alienated present in order to open up the major prospect for the human future, especially at the national level. In this way, with the idea of circular development Frashëri extended the continuity of human values and provided meaning to history as a moral achievement in people's lives and existence.

Most of his verses, from Spring Flowers to Qerbelaja XI, show the extent to which in Frashëri's conception of immortality there is no heaven and hell, divine damnation and reward, but simply a worldly life with the human being at its centre, where heaven and hell are all together, always in permanent and uninterrupted renewal, transformation and regeneration. In an unusual development of heterodox Bektashi conceptions and in contrast to other mystics, for Frashëri metempsychosis and transubstantiation of souls and life after death is neither a promise of recompense nor a threat of condemnation but simply guarantees the transmission of both human and national values from the past to the future: 'Albanians cannot die, They are a people of first rank, Pears fall under the pear tree, Day of today was also yesterday'. ${ }^{59}$

As the defining idea of Frashëri's historical worldview, circular development not only helped him to overcome Manichaean dualism, but it also aimed to resolve the ethical issues of the moral perpetuation of the human being transformed into a higher moral being, which qualified his disposition as an ethical and political thinker and activist committed to the future of his fellow countrymen. As a moral image, the idea of circular development aimed to raise awareness and the sense of sacrifice and self-denial of individual existence, which should guarantee the possibility of moral perpetuation and immortality of the collective and national being. Although the individual physically disappears and dies, they do not morally die and disappear. Only in 
light of the unity and continuity of the nation can the moral perpetuation and immortality of the individual become possible and actual. Where people miss a real individual continuity, they gain a collective moral continuity, as the individual soul passes into the ideal spirit of the nation.

Better than anywhere else, Frashëri's idea of his own mission was expressed through the symbol of the 'candle's words', which is also the first known verse he published in Albanian. The candle is one of the traditional symbols of Persian poetry and Sufi literature, at the core of Islamic mysticism, closely related to the butterfly that burns in the candle's flames, thus underlying the well-known mystical motif of physical self-annihilation of the human being to be merged in God (fana-fi-Haqq). Whereas this expressed a passive philosophy, the idea of finding happiness in a state of mystical intoxication and religious ecstasy, Frashëri innovatively elaborated on the known motif, moving away from the original heightened mystical essence. He built his poem on the symbol of candle-lighting to emphasize his enlightened civic and humanist mission to enlighten his fellow countrymen on their way to freedom and prosperity. So Frashëri indicated an active philosophy, a philosophy of action and sacrifice, becoming himself a spiritual leader of his fellow countrymen, a human torch that illuminated the path to goodness, knowledge, and moral perfection: 'In your midst I stand, And I am going to burn, To provide you with light, To turn your night into day'.60

Metempsychosis or 'reincarnation' within the natural world is accepted as a dogma, for everything and everybody's human life is an individualization of the natural infinite soul, while death is the individual part going back to its primary source 'Light going back to Light' - to become a regeneration of natural life. ${ }^{61}$ However, the form taken in one's reincarnation is determined by one's moral and spiritual progress along a path of life which can only be comprehended, clearly, by one who has been initiated or spiritually enlightened.

In Sufi traditions the theological rationalization of the necessary relationship within spiritual genealogies was articulated through the historical aspect of a supposed divine hierarchical chain (silsila). As argued elsewhere, silsila provided a doctrinal as well as a power line leading to the ultimate source of religion and may be seen as a means to re-assert doctrinal orthodoxy. ${ }^{62}$ By contrast, in Frashëri's conception, special emphasis was given to esoteric knowledge as a privilege not exclusive to a particular genealogical lineage but acquired by spiritual progression, thanks to a divine grace freely and directly bestowed, in close relationship with the expression of Albanian national sentiments and the inculcation of patriotism as the highest of virtues.

With an imagery explored in the explanation of the spiritual chain (silsila) that links all saints back to the Prophet, Frashëri recalled the image of the most popular Bektashi rituals and Albanian gatherings: 'Whosoever obtains a Permission from the Fathers and Mentors enters into the Choir of the Saints, since all the saints are linked together hand in hand, and thus he enters into this company, and into the Chain of these Lords, as in a dance'. ${ }^{63}$ Yet the knowledge of God and the divine light must be synonymous with public knowledge and national education and, clearly, Frashëri openly suggested and theorized the reconciliation of religion with the idea of the nation, even in the most religious of his writings. As with the last canto of Qerbelaja, in his Bektashi Notebook he wrote that the role of Bektashi leaders should be 
guided not only by 'love, brotherhood, unity', but also by 'friendship among all Albanians'. At his hand, 'the Bektashis are brothers with all peoples, they love at heart all other Muslims and Christians alike and they do well with all peoples, but above all they love Motherland and the patriots as this is the best of the best'. Indeed, the Bektashi leaders are not only guides on the path to God, but more importantly they must

strive night and day for the nation which calls them Fathers and urges them to work with the chiefs and the notables for the salvation of Albania and the Albanians, for the education and civilization of their nation and their country, for their language, and for all progress and improvement ... With the chiefs and the notables they must work for unity and fraternity among Albanians, not to let Muslims be divided from the Christians, and the Christians from the Muslims, but let them be and work together, for all progress and improvement, for the Albanians could not be ashamed, but be praised as before always all over the world. ${ }^{64}$

From a comparative Islamic studies and Islamic politics perspective, Frashëri's use of Shiite and Sufi themes and symbolism did not preclude what was, by any measure, an eclectic heterodox fusion of religious and spiritual elements. He was working with some classical ideas, which others before him reflected on at a highly sophisticated level while at the same time popular teachings have adopted them and conveyed them to followers in anecdotes and poems. Frashëri's ideas may go back to the ninth century and they have since become standard teaching at higher levels of Sufi learning and experience. Nevertheless, even though many dedicated Sufis or Bektashis would fully agree with most of his ideas, no one would jump to the conclusions he arrived at.

In the formulation and argumentation of his philosophy, Frashëri made use of religious and realist, pantheistic and Gnostic conceptions, coming from both eastern and western traditions. In matters of theological doctrine, he brought about a new conception of the divine, arguably much more heretical than heterodox Bektashism. He seems to have been in sharp contrast to and even to reject the authority of the orthodox and formalistic interpretations of the Koran, the sacred book of Islam. Using typical themes, Frashëri can even protest God and leave it out of the picture of his cosmogonies, which would be unusual for a Bektashi, at least a difficult line to cross and still remain a Bektashi. As a modern intellectual who regarded some of the core ideas and inspirations of Bektashism seriously, Frashëri took some interesting and important steps in his teaching where he overtly moved away from the classical vision; he narrowed it down or he enlarged it further, depending on how one looks at it.

More than his ethical dualism, Frashëri's pantheistic worldview was an emotional intention of finding or rather inducing high moral values and common sentimentalities, which must oppose any wickedness that could separate or undermine humanity. In this sense, God merged into the universe and humankind was a representation of the morality of love, friendship, kindness, nobility, and humanity at the highest divine level. On the political level, which was related to the former, pantheism became the worldview with which Frashëri aimed to actualize human equality and harmony as much on the universal level among humankind in general as on the level 
of national unity. With the pantheistic concept of God and the monistic principle that all people have one lineage and one creed, they are all of the same clay, they have all one family, one soul, one God and one universe, Frashëri particularly supported the general idea of human unity in the world, aiming to overcome the division of his fellow countrymen in three different religions and promote their unity around God being everywhere, in everything and in everyone. In this way, Albanians could find love in this common Nature-God, which must become their ethical and national support.

Frashëri's mystical and pantheistic musings on nature and on men's place in it yielded to his fundamental political objective, the struggle for the transcendent union of his fellow countrymen. Clearly, the distinct conceptions of God and God's attributes according to separate religions, emphasized by differing services, rituals and institutions, were bringing division and discord among Albanian believers. In contrast, Frashëri went so far as to claim that true Muslims do not necessarily need a mosque and that Arabic and Persian, the languages of the Prophet or the Imams, though intended for religious practice, are not convenient for Albanians. ${ }^{65}$ The extent to which he was far from religious bigotry and dogmatism can be shown in his verses that certainly moved him away from religion altogether: 'With prayer and ritual you cannot find God, neither with Lent nor blessing, as do who don't know'. ${ }^{66}$

For Frashëri, 'the true Bektashi respect a man whatsoever religion he may be, they hold him their brother and their beloved, they never look on him as a stranger. They reject no religion, but respect all. Nor do they reject the books of any religion or the other life ${ }^{6}{ }^{67}$ However, with all his respect due to Bektashism, his own religion, as to all other religions, Frashëri criticized and condemned them for bringing division among Albanians and for the darkness they caused with their propaganda, going so far as to urge Albanians not to regard church and mosque, to pay no heed to Christian priests and Muslim imams when it came to the nation and its salvation: 'Albanian all we are, We are all of the same seed, And the whole of Albania, Is but one as God of oneness! Don't look at religion, Look at motherland ... Let everyone believe, As one can understand, Religion must not set us apart, Religion cannot take us in yoke. ${ }^{68}$

Such a call for the unification of Albanians beyond religious differentiation put Frashëri in clear contradiction to the official religious policy of the Ottoman government and the prejudiced propaganda of other neighbouring and competing nationalisms: 'We are neither Turks nor Giaours, Never say it, never! We are neither Greeks nor Bulgarians, We are just Albanians' ${ }^{69}$ Frashëri did not approach religion in the strict doctrinal and institutional sense or in its outer appearance as a practice with rites and ceremonies, but in another sense exclusively reduced to the inner belief in God and the great everlasting moral duties. Following the logic of his pantheistic teachings aimed to the political intention of excluding any kind of dividing ritual or institution and contrary to the religious propaganda of the time, he urged Albanians to have 'all one belief' in God, claiming that God cannot be that of separate religions but that of pantheism, included and unified as it is into nature and the universe. Taking God from heaven down to earth, he even urged religious leader not to search for God in separate places of worship, simply because God is anywhere in nature and the universe: 'And you priests and dervishes forget church and mosque, for church and mosque cannot be but where God really is, ${ }^{70}$ 
The association of divinity with nature and its relationship to human beings constituted a paradigm of universal harmony that must stimulate a sense of tolerance and respect for everyone regardless of the positive forms of religious affiliation: 'The one who knows oneself, and understands the universe, knows what divinity is, and has humanity in his own way'. ${ }^{71}$ In this way, Frashëri made of pantheism one of the theoretical bases to instil people with new hope, great energy and a resolute belief in their own forces. In his poems, Sufi mysticism is blended with a nature pantheism centred on the Albanian homeland, which became part of the divine scheme. The defiant peaks of the Albanian mountains were assumed to express the will of the people, whereas they point upwards to the skies and ultimately to heaven and divinity. ${ }^{72}$ By singing hymns to Albanian nature and men, if the wonderful harmony he discovered everywhere, if the happiness and joy he saw overall came out because nature and men were indeed God's highest and most beautiful manifestation, then ordinary people's hearts must have been inspired for the greatest effort.

As shown especially in his poetic collection entitled Spring Flowers, just as everything in the world and in life is transformed, renewed and reborn, Frashëri aimed at linking the fate of his fellow countrymen to the fate of their own nation. Namely, through transformations resulting from self-denial and resistance, he intended to reveal and anticipate transformation, renewal and regeneration of the collective being from servitude to national freedom and prosperity. In this way, the pantheistic belief in circular development logically supported Frashëri's transcendental optimism, which was related as much to his belief in God and in the immortality of life in the universe, as to his belief in the recovery, renewal and revival of the freedom and independence of his fellow countrymen. If life is immortal, Albania as one of its expressions is also undying: 'All die, but life cannot shut off; language and motherland remain, inexorably eternal forever'. ${ }^{73}$

Surely, from the wording, Frashëri's pantheism was of an eastern cast, more or less similar to that of Persian or Arabic poets of Sufi sects like the Bektashis, but differed from all of them in content and leanings. In addition, Frashëri's argument of the Universe as the lively representation of God was arguably another way of stating materialist and realist principles, with which he must have tried to create a new secular culture of a more western disposition. Among other things, in his verse on 'the Sun spark toward the violet' he stated his conception of an infinite soul unified with nature and waiting for special conditions to materialize itself into the infinite variety of things of the world: 'Inside that dough was a great soul awaiting to boom out'. ${ }^{74}$

In fact, Frashëri not only acknowledged Deus in rebus, but he explicitly mentioned Spinoza and the celebrated Natura-sive-Deus, while he based his erudite educational writings on nature and humankind mainly on eighteenth-century European rationalism. The pantheistic and materialistic elements found in many of Frashëri's works, particularly in the lyrics on 'Human Heart' and 'Divinity' of the Spring Flowers or in the Universe, clearly show a natural fusion of the parts into the whole, which might be assimilated to an eastern version of Spinoza's universal pantheism and Voltaire's rationalist deism. One might be tempted to say that with his combination of universalistic and humanistic themes from both Islamic and Christian cultures, Frashëri was an Albanian nationalist with a surprisingly cosmopolitan disposition of a 'European' kind, especially with regard to his pan-religious nationalist appeals and his rather 'civic' use of religious ideas and symbolism. 
In spite of his religious faith, he believed that religion put European reason to sleep and that Europe was awaiting enlightened ideas to awake it to its way of progress and civilization. He is quite explicit regarding the Enlightenment that helped him to understand the European situation at the time of the Ottoman conquest in the fifteenth century, while altogether rejecting any religious ideas as 'inhuman darkness' ${ }^{75}$ Again, in spite of his allegiance to Muslim Ottomans, who 'came from the Asian East' and became a threat for Albanians and the whole human civilization in the European West ${ }^{76}$ with his exalted verse on 'the blessed Light that rises from where the sun sets in the west', ${ }^{77}$ he clearly proclaimed his programme of coming back to western Christian Europe.

Arguably in the same way, it is by putting a strong transformational emphasis on the concepts of pantheism, divinity, and spiritual knowledge that Frashëri must have introduced an enlightened rationalist and nationalist dimension into the doctrines of Bektashism. In fact, his non-sectarian, interfaith, and national appeal is not only a characteristic of him and his fellow nationalists, but is also expressed in typically heterodox gnostic, dualistic and pantheistic terms. It is precisely these conceptions that must have provided Bektashism with the theoretical foundation to join the ideology of the Albanian national movement, while Frashëri's elective affinity with Bektashism must have been something like the enthusiasm of western romantics for Catholicism.

Notwithstanding influences and even though often formulated in Bektashi and Sufi terms, the relationship to the ideals of the Albanian liberation movement gives Frashëri's religious discourse a unique originality, with a brand new content and a very worldly shape, especially far away from the Sufi mystical and ecstatic patterns. Owing in the first place to his own literary culture, knowledge of Persian literature and philosophy on the one hand and knowledge of European romanticism and rationalism on the other, the strong moral and enlightened character of Frashëri's religious discourse was conditioned by national historical, sociocultural and political conditions.

Arguably, Frashëri's religious discourse must be considered as an original theological conception, elaborated with particular conviction after the political evolution of the 1890s within the specific conditions of Albanian nationalism. In fact, his religious conceptions were strengthened in their sociocultural dimension and as an expression of opposition to Sunni orthodoxy and its Ottoman stronghold. At his hand, heterodox conceptions like dualism and pantheism became a philosophical and ideological argument, through which he openly conveyed his opposition to Ottoman power and promoted the liberating and emancipatory ideas of the Albanian national movement.

To this extent, it can be argued that Frashëri's dualistic character along with his pantheistic conceptions might have reasonably made it possible for the Bektashi religion to join with an Albanian national ideology. The articulation of contest and liberation ideologies with the hierarchization of covenantal structures of divine mediation is particularly helpful in revealing the organizational and theological character of Bektashism as a mystical, heterodox order throughout its historical transformations. Moreover, Frashëri's strong emphasis on pantheistic worldviews can be thought to have set Bektashism against the Sunni monotheism that served Ottoman imperial centralism. Arguably, whereas the sultan was proclaimed caliph of God according to the principle of one God in Heaven, one sultan on earth, the pantheism that located 
God everywhere and in everyone must have provided a rationale to the project of Frashëri's Albanianism and, alongside many other factors, go some way in helping us to understand the character of Albanian nationalism which generally lacked strong religious attachments.

The above assertions, however, corresponded to an 'imagined' Bektashism by Frashëri, and not necessarily to the actual Bektashism. Indeed, at the conclusion of his Bektashi Notebook, he insisted that Bektashi leaders could be called 'Fathers' and 'Mentors' only when they would adopt the nationalist attitude, which they did not yet: 'When they accomplish these things I call them Fathers and Mentors, but today I cannot call them so', and he urged them 'to be men of truth without vices such as they have now' - that is at the time when he was writing his Bektashi Notebook in 1896. In fact, if Bektashism might have represented a potentially salutary issue for Albanians, this could not result except from the more intellectual conception of Bektashism that Frashëri tried to achieve. He could not be unaware that many of the Bektashi leaders, coming from country families, had limited knowledge. For other nationalists as well, this is what could have made Bektashi leaders inert and impervious to new ideas, as shown by the, at the time, common image of dervishes being doped with opium. ${ }^{78}$ The problem remained, on the one hand, in the fact that the Bektashi order represented a very weak minority of Albanians and, on the other, in the natural context and way of life of Bektashi followers. Bektashism evolved around the worship of saints, the veneration of religious leaders, requests for intercession, and respect of a brotherhood ethics and fraternity, but was very distant from the kind of national historical memory that Frashëri himself and other Albanian activists aimed to construct at this time.

Frashëri was not a unique leader, but the quality of his verse and his large audience and ritualized reception among Albanian-speaking people, together with the relevance of his nationalist and educational activities, arguably placed him at the forefront of the avant-garde of the Albanian national movement. As with his History of Skanderbeg, grounded in Christian symbolism but encompassing any religion in order to provide Albanians with an idyllic situation of common faith to be found in the heroic past, he became defender of Bektashism not merely because of any personal special link or conviction. Just as with the choice of Skanderbeg's symbol, by means of Bektashism he could better proclaim his credo in opposition to the Ottoman administration. As long as Ottoman political power coincided at an ideological level with Islamic religion, all deviation from dogmatic and orthodox Islam was assumed to take on a political meaning of opposition. ${ }^{79}$ By the same token, while voluntarily putting forward and developing this very character, he aimed to bring Bektashism closer to his own theory of Albanian nationalism.

To this extent, Albanian nationalism and the construction of the Albanian nation could not by any means be an offspring emanating exclusively from Bektashism, as some specialists in the area have claimed. ${ }^{80}$ Admittedly, during the national movement in the late nineteenth century the Bektashi network must have been used by some Albanian nationalists and there is also a generally held opinion that the Bektashis played a significant role in the national movement in Albania from 1878 onwards. Frashëri's elder brother - the leading member of the League of Prizren (1878-81) - seems to have succeeded in using the influence that the Bektashi leader in his own natal village enjoyed in the area to the benefit of his action undertaken in 
favour of an autonomous Albania against the threat of a transfer of territories to Greece, since in May 1878 he must have organized a meeting of South Albanian notables in the Bektashi convent at Frashëri village. ${ }^{81}$

However, this might be another instance of the myths surrounding the Bektashis. If the memory of the persecutions of the Bektashis in 1826, when their brotherhood was prohibited by Sultan Mahmud II, is used later in order to explain the standpoint of Bektashis in favour of Albanian autonomy, nothing tells us that it was really so in 1878. In the same way, the claim that in 1877 the religious leader of Frashëri village could have sent one of his assistants, a certain Adem Baba native of Gjakova, to found a Bektashi convent in the Kosova town of Prizren and to prepare the ground for the League ${ }^{82}$ is doubtless a construction after the fact, intended to relate Bektashism to what will be considered later as the crucial episode in the move towards Albanian independence.

At least the data accumulated by Nathalie Clayer show that most of the Bektashi foundations in Albania were established at the turn of twentieth century ${ }^{83}-$ at the expense of other dervish orders like the Halvetis - when a resurgence of the Bektashi order took place rather as a result of the national movement. The abovementioned Bektashi convent of Prizren, for example, must have been founded by Adem Baba only after $1890 .^{84}$ It is above all since the second part of the 1890 s that the Bektashis actually started to be very active in the development of both cultural and national movements in south and central Albania, with some Bektashi foundations becoming centres of nationalist propaganda and later, in 1907-08, even places of refuge for armed nationalist bands. ${ }^{85}$ In fact, after 1908, in spite of a short-lived alliance with the Young Turks, an increasing number of Bektashi leaders firmly adopted Albanian nationalist ideas.

Even though Bektashi leaders were often only indirectly involved, at their followers' instigation, the implication of Bektashism in the propagation of Albanian nationalism must have drawn the suspicion of Ottoman authorities which relied on local Sunni Muslims to enforce laws, conduct searches and proceed with arrests and the closing down of some Bektashi foundations. As Ottoman policy emphasized orthodox Sunni Islam, taking these steps must have contributed in reinforcing not only opposition to the Ottoman administration but also the opposition of Bektashism to the established Sunni religion.

An overall combination of these conditions must have paved the way for the extraordinary popularity of the Bektashis in Albania and the subsequent introduction of elements of nationalist ideology into their religious doctrine. It seems reasonable therefore to consider things the other way around. Namely, it is the new Albanian Bektashism that might have become the offspring of the Albanian national movement, especially after the elaboration of its heretical doctrines instilled by Frashëri and other influential nationalists, much in the same way as Kizilbash ideology once became the instrument of Safavid policy against Ottoman power in the early sixteenth century.

In turn, like the later development of Kizilbash-Alevi politics in contemporary Turkey, Bektashism in Albania has often been idealized as one of the embodiments of the Albanian Volksgeist, i.e. the spirit or genius which is supposed to mark the thoughts and feeling of the Albanian nation and people, which Bektashi leaders later exploited in a deliberate attempt to make Bektashi ideas attractive among non-Bektashis in 
order to swell the ranks of the Order. It is this kind of instrumental politics that must have contributed to the purportedly active role claimed by the Bektashis in the framework of an autonomous and, later, independent as well as, to some extent, communist and post-communist Albania. ${ }^{86}$ In this way, like their former fellows in the Ottoman Empire and contemporary Turkey, ${ }^{87}$ the Bektashis will reassert their contribution to the construction of the Albanian nation and anticipate political benefit.

The specific cultural and political instrumentality of religion for the ideals of the nation exhibited by nineteenth-century Albanian nationalism certainly appears unusual, and difficult to grasp, if one schematically employs traditional categories developed in current scholarship to deal with these questions. However, a combination of the main nationalist projects and intellectual speculations, linked to a careful examination of the historical and literary contextualization in comparative political perspective, is likely to produce a more sophisticated understanding of the myth of the relationship of Bektashism to the emergence of the Albanian national movement.

While analysing the historical, cultural, and literary terrain in which certain influential ideas in Albanian intellectual history emerged, the aim of this article was to frame the argument so as to remove the close association of a major figure of Albanian nationalism with Bektashism and present Frashëri as an intellectual whose literary and intellectual output is about national values and nation-building endeavours. More simply, as an implication of our discussions in this paper, Frashëri is an Albanian national figure in whom the Bektashi have emphasized the Bektashi heritage so that they themselves could appear more loyal and better situated regarding matters of nationhood especially by comparison to either Sunni Muslims or Orthodox Christians of Albanian descent.

In methodological terms, we tried to engage with a comparative analysis of ideas rather than with a search for positive literal proof. This approach might not be exhaustive, and certainly a number of questions remain open. However, if this article has managed to provoke at the very least a non-stereotyped discussion through an interesting set of cogent reflections on Frashëri and the association of Bektashism with the emergence of the Albanian national movement, it will hopefully constitute a starting point for further, deeper enquiries that can suggest alternative explanations.

\section{Notes}

1. A. Doja, 'The Politics of Religious Dualism: Naim Frashëri and his Elective Affinity to Religion in the Course of 19th-Century Albanian Activism', Social Compass: International Review of Sociology of Religion, Vol.60, No.1 (2013), pp.115-33.

2. F. Barth, 'Introduction', in Ethnic Groups and Boundaries: The Social Organization of Culture Difference (London: Allen \& Unwin, 1969), pp.9-38.

3. A. Doja, 'Ethnicité, construction nationale et nationalisme dans l'aire albanaise: Approche anthropologique du conflit et des relations interethniques', Ethnologia Balkanica: Journal for Southeast European Anthropology, Vol.3 (1999), pp.155-79.

4. A. Doja, 'The Politics of Religion in the Reconstruction of Identities: The Albanian Situation', Critique of Anthropology, Vol.20, No.4 (2000), pp.421-38.

5. N. Clayer, Aux origines du nationalisme albanais: la naissance d'une nation majoritairement musulmane en Europe (Paris: Karthala, 2007).

6. S. Skendi, The Albanian National Awakening, 1878-1912 (Princeton, NJ: Princeton University Press, 1967), pp.469-70. 
7. P. Bartl, Die albanischen Muslime zur Zeit der nationalen Unabhängigkeitsbewegung, 1878-1912, Albanische Forschungen, 8 (Wiesbaden: Harrassowitz, 1968).

8. A. Turabiu, Historia e pergjithshme e Bektashinjvet [General history of the Bektashis] (Tirana, 1929); B. Rexhebi, Misticizma Islame dhe Bektashizma [Islamic mysticism and Bektashism] (New York: Waldon Press, 1970).

9. A. Popovic, L'islam balkanique: les musulmans du sud-est européen dans la période post-ottomane, Balkanologische Veröffentlichungen, 11 (Wiesbaden: Harrassowitz, 1986); N. Clayer, L'Albanie, pays des derviches: les ordres mystiques musulmans en Albanie à l'époque post-ottomane, 1912-1967, Balkanologische Veröffentlichungen, 17 (Wiesbaden: Harrassowitz, 1990); A. Popovic and G. Veinstein (eds.), Bektachiyya: études sur l'ordre mystique des Bektachis et les groupes relevant de Hadji Bektach (Istanbul: Isis, 1995); J. Norton, 'The Bektashi in the Balkans', in C. Hawkesworth, M. Heppell and H.T. Norris (eds.), Religious Quest and National Identity in the Balkans, School of Slavonic and East European Studies, University College London (New York: Palgrave, 2001), pp.168-200; F. Kressing, 'A Preliminary Account of Research Regarding the Albanian Bektashis: Myths and Unresolved Questions', in F. Kressing and K. Kaser (eds.), Albania, A Country in Transition: Aspects of Changing Identities in a South-East European Country, Schriften des Zentrum für Europäische Integrationsforschung, 51 (Baden-Baden: Nomos, 2002), pp.65-91.

10. R.M. della Rocca, Nazione e religione in Albania (1920-1944) (Bologna: Mulino, 1990).

11. Naim Frashëri started his writings in Turkish with a Grammar of Persian 'according to the new method' (Kavaidi Farisiyye ber tarzi nevin, Istanbul, 1871, 1887), a knowledge book on inventions and discoveries (Ihtiraat ve kessfiyyat, Istanbul, 1881), and a poetic novel adapted from the French (Fusuli erbea [Four seasons], Istanbul, 1884). His first poetic masterpiece was also written in Persian (Tehayyülat [Reveries], Istanbul, 1884), which later gained him the title of the 'Muhammad Iqbal of the West' (H.T. Norris, Popular Sufism in Eastern Europe: Sufi Brotherhoods and the Dialogue with Christianity and 'Heterodoxy' (London and New York: Routledge, 2006), p.32), before he produced his great poetic and educational works in Albanian: Fjala Fluturake [Flying speech], Bucharest, 1884; Bagëti e Bujqësija [Bucolics], Bucharest, 1886; Këndonjëtoreja e këndimit çunavet [Reader for boy schools], 2 vols., Bucharest, 1886; Istori e përgjithëshme për mësonjëtoret të para [General history for primary schools], Bucharest, 1886; Vjersha për mësonjëtoret të para [Verses for primary schools], Bucharest, 1886; Dituritë për mësonjëtoret të para [Knowledge for primary schools], Bucharest, 1888; Luletë e Verësë [Spring flowers], Bucharest, 1890; Mësime [Teachings], Bucharest, 1894; Parrajsa dhe Fjala Fluturake [Heaven and flying speech], Bucharest, 1894; Gjithësija [Universe], Bucharest, 1895; Fletore e Bektashinjët [Bektashi notebook], Bucharest, 1896; Qerbelaja [Karbala], Bucharest, 1898; Istori e Skënderbeut [History of Skanderbeg], Bucharest, 1898; Istori e Shqipërisë [History of Albania], Sofia, 1899; and Shqipëria [Albania], Sofia, 1902. He is also the first translator of Homer's Iliad I from Ancient Greek into Turkish (Istanbul, 1886) and into Albanian (Bucharest, 1896). At the same time he wrote in Modern Greek a political pamphlet in verse ( $O$ alithis pothos ton Skypetaron [The real wish of Albanians], Bucharest, 1886) and an original poem in eight cantos on his conception of love (O eros, Constantinople, 1895). His Selected Works are published in two volumes (Tirana, 1980-85), alongside several editions of his Complete Works in seven volumes (Prishtina, 1978, Prishtina, 1986, Tirana, 1995-2001, Tirana, 2007).

12. Frasheri's Bektashi Notebook (Bucharest, 1896, Sofia, 1908, Thessalonica, 1910, Korça, 1921, Tirana, 1996 ) is translated into English from the Greek (F. Hasluck, Christianity and Islam under the Sultans, 2 vols. (Oxford: Clarendon, 1929/2000), pp.444-53), in French as far back as 1898, and in Italian in 1918. The complete French translation is published in Revue du Monde Musulman, Vol.49 (1922), pp.105-20, while a scholarly bilingual Albanian and German edition with full text and critical notes is published in Balkan-Archiv, Vol.2 (1926), pp.226-56.

13. The relationship of religion and national ideas in Frasheri's conception has been very often uncritically investigated by many scholars on either side of religious or national-communist lines, which may include historical contextualization (D. Shuteriqi, Naim Frashëri: jeta dhe vepra [Naim Frashëri: life and work] (Tirana: 8-Nentori, 1982)), textual analysis (B. Qerimi, Poetika e Naim Frasherit [The poetics of Naim Frashëri] (Tirana: Toena, 1979/2000); R. Qosja, Porosia e Madhe: Monografi mbi Krijimtarinë e Naim Frashërit [The great commandment: a monograph on the works of Naim Frashëri] (Tirana: Toena, 1986/2000); J. Bulo, Tipologjia e lirikës së Naim Frashërit [Typology of Naim Frashëri's poetry] (Tirana: Shkenca, 1999)), textual reading of Oriental influences (Q. Qazimi, Ndikime orientale në veprën letrare të Naim Frashërit [Oriental influences in Naim Frashëri’s literary 
opus] (Prishtina, Kosova: Këshilli i Bashkësisë Islame të Gjilanit, 1996)), educational history (X. Murati, Naim Frashëri: Pikëpamjet edukativo-arsimore [Naim Frashëri: educational worldviews] (Shkup: Flaka e Vëllazërimit, 1993)), history of ideas (Z. Xholi, Naim Frashëri midis së kaluarës dhe së sotmes [Naim Frashëri between past and present] (Tirana: Luarasi, 1998)), or simply apologetic kitsch (M. Zeqo, Syri i Tretë: Naim Frashëri dhe Bektashizmi [Third eye: Naim Frashëri and Bektashism] (Tirana: Medaur, 2001); L. Bica, Naimi në Konstandinopojë, 2 vols. (Tirana: Universiteti Kristal, 2009)).

14. Naim Frasheri worked in a high official position, for a time inspector and thereafter director of the Office of Censorship in the Ministry of Religious and Public Instruction of Ottoman Government.

15. His younger brother Shemseddin Sami Frasheri (1850-1904) gained a place in Ottoman literature as a talented author and contributed to Turkish language reforms with several works on Modern Turkish language and grammar (1886-98), a series of standard Turkish and bilingual French-Turkish and Arabic-Turkish dictionaries (1882-1905), and a dictionary of the Classical Ottoman Turkish language (Kamus-ı-Türki) in two volumes (1899-1900), still widely used as a reference work (reprints in 1978 and 1998). As a self-taught linguist, lexicographer, novelist, journalist and encyclopaedist, Shemseddin Sami Frasheri was one of the most productive intellectuals of the Ottoman Empire in the second half of the nineteenth century and has been praised in both modern Turkish and communist Albanian historiographies for his contributions to Turkish or Albanian nationalism respectively (B. Bilmez, 'Sami Frashëri or Shemseddin Sami? Mythologization of an Ottoman Intellectual in the Modern Turkish and Socialist Albanian Historiographies based on Selective Perception', Balkanologie: Revue d'Études Pluridisciplinaires, Vol.7, No.2 (2003), pp.19-46). One of his novels is commonly taken to be the first novel written in Turkish and his Universal Encyclopaedia (Kamîs-ül-Âlâm) in six volumes (1889-98) is known to be the first encyclopaedia printed in Turkish, while one of his political pamphlets (Shqipëria ç'ka qenë, ç’është e çdo të bëhetë [Albania: what it was, what it is and what will become of it], Bucharest, 1889) is known to be the theoretical commentary that became the manifesto of Albanian nationalism.

16. The issue is briefly mentioned in an early essay first published in 1925 (K. Maloki-Lepeteni, Oriental apo Okcidental (Tirana: Plejad, 2003), pp.76-102), but to the best of our knowledge has never captured the interest of modern scholars. Supposed links, like taking part in a gathering of the southern branch of the League (Shuteriqi, Naim Frashëri, p.227), have yet to be substantiated.

17. His elder brother Abdyl Frasheri (1839-92) distinguished himself as a political personality from 1877, when the Russo-Turkish War (1877-78) severely jeopardized the integrity of the Albanian lands. Chairing an ad hoc Albanian Committee of Janina, he drafted the first declaration of independence for Albania and proposed to form a political and military Greco-Albanian coalition against the Ottoman Empire. Thereafter a member of parliament of the Ottoman Empire, he was elected chairman of the Central Committee of Istanbul for Defending Albanian Rights and he contributed to the elaboration of the new political platform of the national movement towards the creation of an autonomous Albanian province under the suzerainty of the Ottoman Empire. After the foundation of the League of Prizren in 1878, which adopted this platform, he distinguished himself as the most important leader of the League, in spring 1879 he headed the Prizren League delegation to the capitals of major powers to protect the integrity of Albanian-speaking lands and the rights of Albanians, and he became the main promoter of the interim government formed in Prizren in early 1881. In this capacity, he contributed to the political and military preparations for the protection of autonomy against the Ottoman military expedition that suppressed the League of Prizren in 1881. Afterwards, he was arrested and sentenced to death by an Ottoman Special Trial.

18. Tehayyülat, 1884. Despite efforts of Albanian scholars, it seems difficult to locate Frasheri's poetic beginnings in foreign languages as part of the assumed romanticism of the Albanian national movement, especially in light of the processes that were taking place in Albanian literature and culture in the last quarter of nineteenth century (see Bulo, Tipologjia e lirikës së Naim Frashërit, pp.131-5.).

19. While his younger brother Shemseddin Sami Frasheri was a part of the Albanian 'we-group', he often used 'we'-form in talking about the Turks and played an important role in the 'emergence of Turkish nationalism' and in the history of 'Panturkism'. However, he was also an active participant in Albanian nationalism and declared in his important book in 1899 that there was no other solution for Albanians than having an independent state. His 'separatist' attitude is not easy to acknowledge for the majority of Turkish scholars, but has been overemphasized by their Albanian colleagues, who in 
their turn cannot try to understand all dimensions of his ideas because they neglect his engagement with Turkish nationalist circles and the Turkish nationalist character of some of his writings.

20. Doja, 'The Politics of Religious Dualism', pp.115-33.

21. A. Doja, 'A Political History of Bektashism from Ottoman Anatolia to Contemporary Turkey', Journal of Church and State, Vol.48, No.2 (2006), pp.421-50.

22. A. Doja, 'A Political History of Bektashism in Albania', Totalitarian Movements and Political Religions, Vol.7, No.1 (2006), pp.83-107.

23. A. Doja, 'Histoire et dialectique des idéologies et significations religieuses', European Legacy Towards New Paradigms: Journal of the International Society for the Study of European Ideas, Vol.5, No.5 (2000), pp. 663-86.

24. Doja, 'The Politics of Religious Dualism'.

25. M.G.S. Hodgson, The Venture of Islam: Conscience and History in a World Civilization, 3 vols. (Chicago: University of Chicago Press, 1974).

26. See notes 7 and 8 .

27. Norris, Popular Sufism in Eastern Europe.

28. M. Moosa, Extremist Shiites: The Ghulat Sects, Contemporary issues in the Middle East (New York: Syracuse University Press, 1988).

29. I. Melikoff, Hadji Bektach, un mythe et ses avatars: genèse et évolution du soufisme populaire en Turquie, Islamic History and Civilization, 20 (Leiden: Brill, 1998).

30. Norris, Popular Sufism in Eastern Europe, pp.31-41.

31. A. Doja, 'Spiritual Surrender: From Companionship to Hierarchy in the History of Bektashism', Numen: International Review for the History of Religions, Vol.53, No.2 (2006), p.473.

32. Reveries I, IX.21-3; Spring Flowers XIV.29-32.

33. Bulo, Tipologjia e lirikës së Naim Frashërit, p.141.

34. E.g. Xholi, Naim Frashëri.

35. Bulo, Tipologjia e lirikës së Naim Frashërit, p.140.

36. Reveries XX.

37. Shuteriqi, Naim Frashëri, p.184.

38. Spring Flowers XIX.1-4.17-20.

39. Maloki-Lepeteni, Oriental apo Okcidental, pp.73-102.

40. Qerimi, Poetika e Naim Frashërit; Qosja, Porosia e Madhe, pp.155-79; Xholi, Naim Frashëri; Bulo, Tipologjia e lirikës së Naim Frashërit, pp.68-76.

41. Heaven III.17-20.

42. Qerbelaja XXV.37.

43. Heaven III.23-6.

44. Bektashi Notebook.

45. Reveries I.57-8.

46. See Xholi, Naim Frashëri, p.104.

47. Bulo, Tipologjia e lirikës së Naim Frashërit, p.165.

48. Spring Flowers XIX.25-8.

49. Ibid. VII.29-32.

50. Ibid. XIX.49-56.

51. Verses for Primary Schools XL.43-4.51-2.

52. Spring Flowers XIX.133-6.

53. J.K. Birge, The Bektashi Order of Dervishes (London: Luzac Oriental, 1937/1994), p.282.

54. Spring Flowers XIX.113-16.

55. Reveries.

56. Qerbelaja XI.31-40.

57. Qerimi, Poetika e Naim Frashërit, pp.211-28; Qosja, Porosia e Madhe, pp.172-3.

58. In his History of Skanderbeg (1898) Frashëri narrated the exploits, successes and failures of the Albanian national hero against the Ottoman invaders in the fifeenth century. In the history of Albanian literature this work is held to be his most famous and greatest poetic aspiration, a supreme attempt by the poet to project his idealism, patriotism and sense of Albanian cultural continuity back into the past when for twenty-five years the Albanians had fought under Skanderbeg's leadership (14431468) to resist Ottoman annexation. For a contextualization of this monumental epic within Frashëri's work, see Doja, "The Politics of Religious Dualism”. 
59. Heaven III.225-8.

60. Verses for Primary Schools I.1-4.

61. Qerbelaja VI.65.

62. Doja, 'Spiritual Surrender', pp.486-7.

63. Bektashi Notebook

64. Ibid.

65. It was not only in his Bektashi Notebook that Frasheri advocated the dissociation of Albanian Bektashism from Ottoman influence by urging Albanian Bektashis to have their own independent leader of Albanian descent; it is also claimed there is some evidence that Frasheri even attempted to translate the Koran into Albanian, at a time when this could be considered as an outrageous blasphemy (Zeqo, Syri i Tretë, p.20.).

66. Spring Flowers XIX.57-60.

67. Bektashi Notebook

68. Heaven III.149-54.167-70.

69. Ibid. III.35-8.

70. Ibid. III.249-52.

71. Verses for Primary Schools III.21-4.

72. Bucolics.

73. Spring Flowers XVIII.73-6.

74. Verses for Primary Schools XXIX.62-4.

75. History of Skanderbeg IV.17-28.

76. Ibid. I.85-100.

77. Spring Flowers IV.11-12.

78. Clayer, Aux origines du nationalisme albanais, p.484.

79. See Xholi, Naim Frashëri, p.75.

80. N. Clayer, Religion et nation chez les Albanais (XIXe-XXe siècles), Analecta Isisiana, 64 (Istanbul: Isis, 2002), pp.103-35; Ger Duijzings, Religion and the Politics of Identity in Kosovo (London: Hurst, 2000), pp.157-75.

81. Clayer, Aux origines du nationalisme albanais, p.476.

82. Rexhebi, Misticizma Islame dhe Bektashizma, p.339.

83. Clayer, L'Albanie, pays des derviches.

84. Clayer, Aux origines du nationalisme albanais, p.477.

85. Clayer, Religion et nation chez les Albanais, pp.103-35.

86. Doja, 'A Political History of Bektashism in Albania'.

87. Doja, 'A Political History of Bektashism from Ottoman Anatolia to Contemporary Turkey'. 